\title{
Laboratory Measurement of the Corrosion of Ferrous Metals in Soils
}

\author{
W. J. Schwerdtfeger
}

\begin{abstract}
A method is described for setting up soil-corrosion cells using a soil-wetting procedure that gives reproducible results. By measuring the weight losses on cell electrodes made of steel and of cast iron after exposure to various soils for 6 months, it was possible to compare the effects of corrosion on the two materials. It was also found that the electrode weight losses correlated with the weight losses and maximum pitting on wrought ferrous specimens exposed for 10 years at the field test sites. Because the laboratory soils covered the range of corrosivity peculiar to soils, it was possible to derive empirical equations for predicting weight loss and pitting at the end of 10 years for presumably any soil. It is also shown how reasonable adjustments can be made for areas other than that of the field specimens and for exposure periods other than $10^{\mathbf{y}}$ years.
\end{abstract}

\section{Introduction}

A review of the field corrosion data obtained by the National Bureau of Standards invariably results in the conclusion that no single soil property is a good measure of its corrosivity toward iron or steel. Because the normal corrosion of iron and steel underground is an electrolytic phenomenon, several accelerated laboratory and field tests based on electrical measurements have been devised that purport to measure the corrosivity of soils. Ewing $[1]^{1}$ has pointed out that the majority of such tests in effect really measures soil resistivity. Whereas measurements of soil resistivity made along a pipe line might correlate very well with the evidence of corrosion on the surface of that particular pipe, it is also true that there is no general correlation between the corrosion of ferrous metal exposed to different soils and the soil resistivity.

Denison [2,3] described a laboratory corrosion cell in which an electromotive force was developed by differential-aeration between two steel electrodes separated by soil as the electrolyte. The maximum current measured between the electrodes over a 2veek period was used as an index of soil corrosivity. A fair correlation was obtained between laboratory and field data except for the soils of relatively high resistivity. In such soils, because of local action, the anode weight losses were more significant than the sell currents as an index of soil corrosivity.

Logan, Ewing, and Denison [4] have shown by field exposure tests that the corrosion rate of iron and steel in soils varies from an almost constant rate with time in some soils to virtual cessation within a few years in other soils. Such information is of great value to those concerned with underground construction. The time required to conduct such tests in the ield, however, is long, and the required information cannot be obtained, in many cases, when it is most zeeded. A suitable laboratory test using the soil in auestion and operating over a sufficiently long period o reflect any change in the rate of corrosion of iron and steel with time is most desirable. The data from such a test should be correlated with known fieldexposure data so that the results can be correctly

\footnotetext{
3 Figures in brackets indicate the literature references at the end of this paper.
}

interpreted. The extensive field exposure tests of the National Bureau of Standards provide a considerable volume of data that can be used for this purpose.

The corrosion cell used for this investigation is a modification of the cell described by Denison. It lends itself to better reproducibility than the original cell and will remain operative for a longer period of time. Although electrical measurements can be made that account for all weight loss of steel exposed to soils [5], weight loss is used as the corrosion index, because electrical measurements would have to be made frequently to account for the change in corrosion rate with time.

\section{Experimental Methods}

\section{1. Description of the Corrosion Cell}

The corrosion cell and all of its components are shown in figure 1. The cell consists essentially of a weighed iron or steel anode, A, and a weighed perforated cathode, B, made of the same material, both provided with electrical connections and separated by soil of a definite moisture content. The soil is contained in two Lucite cylinders, C. Other parts of the cell that serve to hold the soil in place and thus insure good contact with the electrodes are two stainless-steel screens, D and E, the rubber stopper, H, and the rubber band, G. The components are joined with asphalt, $\mathrm{F}$, which also serves as a sealer. Aeration of the cathode is accomplished by adjusting the moisture content of the soil, and access of air to the anode is restricted by mechanically working the layer of soil in contact with it, which results in a difference of potential between the electrodes. Details concerning the preparation of the cell are given in the appendix.

\subsection{Use of the Corrosion Cell}

The behavior of the corrosion cells in reflecting the effect of time on corrosion of iron or steel is illustrated by figure 2. The cell currents were measured with a zero-resistance milliammeter without permitting the cells to be on open circuit. The currents for each soil are the average values for four cells. It will be noted from the table in the figure 


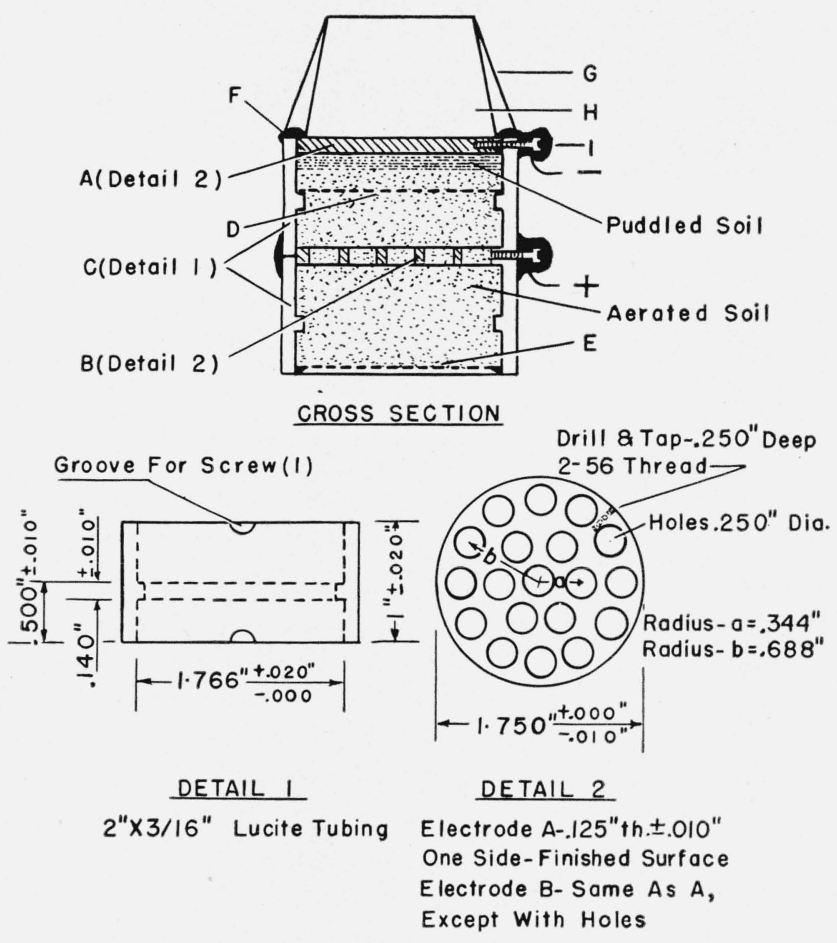

Figure 1. Soil-corrosion cell.

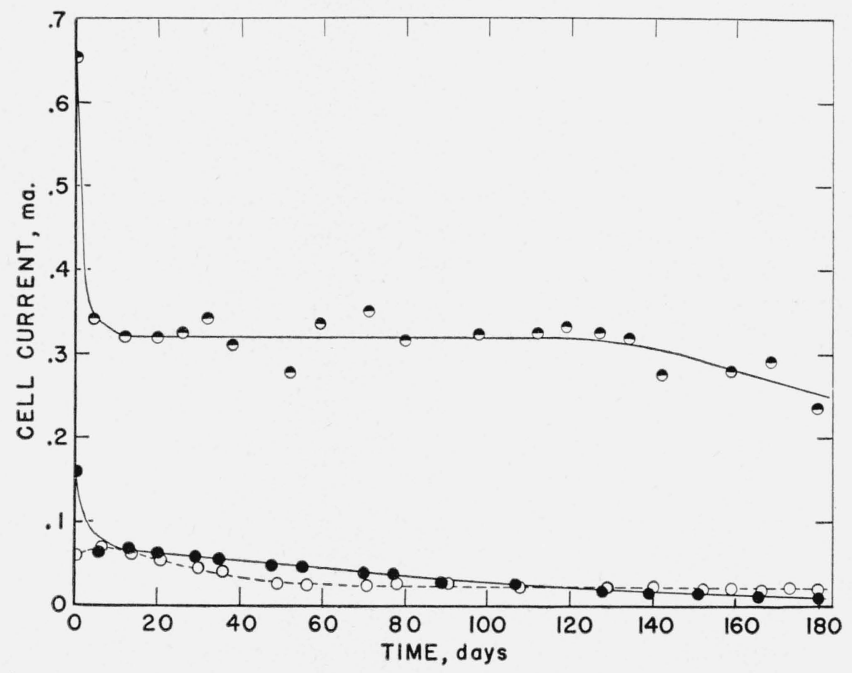

Figure 2. Effect of exposure time on the corrosion of steel in soils.

\begin{tabular}{|c|c|c|c|c|c|}
\hline Symbol & Soil & $\begin{array}{l}\text { Resis- } \\
\text { tivity }\end{array}$ & $\begin{array}{c}\text { Cell } \\
\text { current } 1\end{array}$ & $\begin{array}{l}\text { Weight } \\
\text { loss of } \\
\text { cell elec- } \\
\text { trodes }{ }^{2}\end{array}$ & $\begin{array}{c}\text { Corrosivity of } \\
\text { soil }^{3}\end{array}$ \\
\hline 8 & $\begin{array}{l}64 \\
62 \\
26\end{array}$ & $\begin{array}{c}\text { Ohrne-cm } \\
62 \\
6922 \\
2980\end{array}$ & $\begin{array}{c}m a \\
0.280 \\
.030 \\
.035\end{array}$ & $\begin{array}{l}2.53 \\
1.05 \\
0.56\end{array}$ & $\begin{array}{l}\text { Most. } \\
\text { Intermediate. } \\
\text { Least. }\end{array}$ \\
\hline
\end{tabular}

1 Calculated from the area under a line through the points.

${ }^{2}$ Combined weight loss of the anode and cathode exposed for 180 days, in ounces per square foot.

3 Order shown by the field-exposure tests. that the electrode weight losses indicate the actual order of corrosivity of the soils, whereas the average cell currents in soils 62 and 26 are in reverse order because of the soil resistivities. However, based on field data of Denison and Romanoff [6] the curves do reflect the effect of time on the rate of corrosion of ferrous materials in the three soils. The field data reveal a fairly constant rate of corrosion of wrought materials exposed to soils 64 and 62 over a period of 14 years and a stifling effect in well-aerated soils similar to soil 26 . It will be noted, figure 2 , that in soil 26 the cell current gradually decreases, whereas in soils 64 and 62 after the initial decrease the currents are relatively steady.

As a result of this and other experiments, 6 months was chosen as the minimum time required for measuring soil corrosion. Although the laboratory results are based on the weight lost by the cell electrodes, the cell current serves to reveal the quality of a cell. If a diverse cell, indicated by incorrect polarity or relatively low current, exists in a particular soil group 2 weeks after assembly time, that cell should be replaced. Six months after assembly the corrosion cells are taken apart and the electrodes cleaned by methods [7] already described. The average combined loss of metal on the anodes and cathodes for the four cells is used as the corrosion index.

\section{Comparison of the Corrosion of Steel and Cast Iron}

\subsection{Weight Loss in the Laboratory Tests}

Although the laboratory corrosion test was planned primarily to show the relative effects of various soils on ferrous materials, to be shown later, the sensitivity of the test can be better evaluated if it is possible to detect differences in the corrodibility of commonly used plain ferrous materials when exposed to a given soil environment. To that end, corrosion cells were assembled with both steel and cast-iron electrodes,

Table 1. Properties of the soils

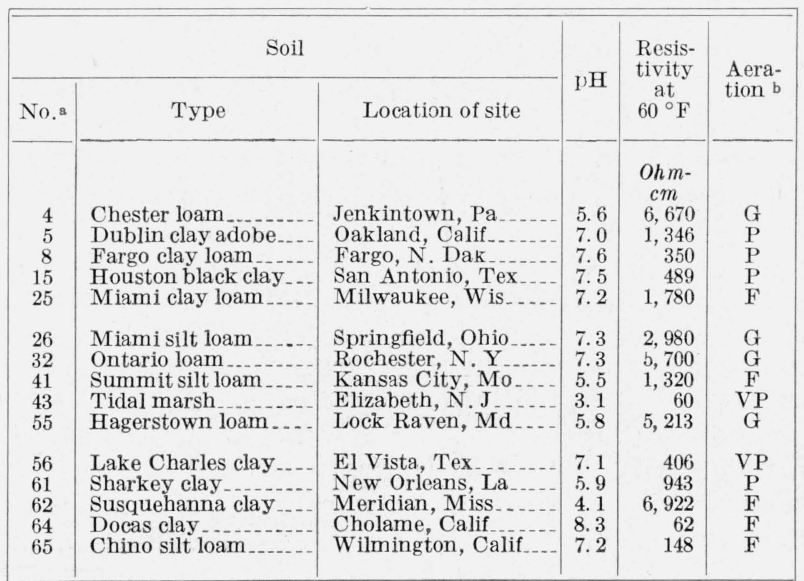

a Soil number also refers to site number as specified in the NBS soil-corrosiou studies.

b A eration of soils: G, good; F, fair; P, poor; VP, very poor. 
TABLE 2. Comparison of the corrodibility of steel and cast iron in the laboratory

\begin{tabular}{|c|c|c|c|c|c|c|c|c|c|c|}
\hline \multicolumn{11}{|c|}{ Loss in weight of cell electrodes in 6 months } \\
\hline \multirow{2}{*}{ Soil } & \multicolumn{3}{|c|}{ Steelb } & \multicolumn{3}{|c|}{ Cast iron ${ }^{\mathrm{c}}$} & \multirow{2}{*}{$\begin{array}{c}\text { Difference } \\
\text { between the } \\
\text { means, } w_{1}-w_{2}\end{array}$} & \multirow{2}{*}{$\begin{array}{l}\text { Standardd } \\
\text { error of the } \\
\text { difference, } \\
\sigma\left(w_{1}-w_{2}\right)\end{array}$} & \multirow{2}{*}{$\begin{array}{l}\text { Value e } \\
\text { of } t\end{array}$} & \multirow{2}{*}{$\begin{array}{l}\text { Probability of } \\
\text { difference due } \\
\text { to chance }\end{array}$} \\
\hline & $\begin{array}{l}\text { Number } \\
\text { of cells }\end{array}$ & Mean $w_{1}$ & $\begin{array}{l}\text { Standard } \\
\text { error, } \sigma_{w_{1}}\end{array}$ & $\begin{array}{l}\text { Number } \\
\text { of cells }\end{array}$ & Mean $w_{2}$ & $\begin{array}{l}\text { Standard } \\
\text { error, } \sigma_{w_{2}}\end{array}$ & & & & \\
\hline $\begin{array}{l}4 \\
5 \\
8 \\
25 \\
26\end{array}$ & $\begin{array}{l}4 \\
8 \\
4 \\
4 \\
4\end{array}$ & $\begin{array}{c}o z / f t^{2} \\
0.61 \\
1.97 \\
0.89 \\
.20 \\
.56\end{array}$ & $\begin{array}{c}0 z / f t^{2} \\
0.065 \\
.14 \\
.045 \\
.021 \\
.049\end{array}$ & $\begin{array}{l}4 \\
7 \\
6 \\
4 \\
4\end{array}$ & $\begin{array}{l}o z / f t^{2} \\
0.85 \\
1.82 \\
1.46 \\
0.46 \\
.65\end{array}$ & $\begin{array}{l}o z / f t^{2} \\
0.028 \\
.25 \\
.13 \\
.056 \\
.037\end{array}$ & $\begin{array}{r}0 z / f t^{2} \\
-0.24 \\
+.15 \\
-.57 \\
-.26 \\
-.09\end{array}$ & $\begin{array}{c}0 z / f t^{2} \\
0.071 \\
.29 \\
.14 \\
.060 \\
.061\end{array}$ & $\begin{array}{l}3.4 \\
0.5 \\
4.1 \\
4.3 \\
1.5\end{array}$ & $\begin{array}{c}\text { Percent } \\
<2 \\
60 \\
<1 \\
<1 \\
18\end{array}$ \\
\hline $\begin{array}{l}32 \\
436 \\
56 \\
64\end{array}$ & $\begin{array}{l}4 \\
4 \\
4 \\
4 \\
4\end{array}$ & $\begin{array}{l}.37 \\
1.36 \\
2.17 \\
1.05 \\
2.53\end{array}$ & $\begin{array}{l}.040 \\
.18 \\
.072 \\
.098 \\
.20\end{array}$ & $\begin{array}{l}4 \\
4 \\
4 \\
4 \\
4\end{array}$ & $\begin{array}{l}.53 \\
3.40 \\
2.33 \\
1.79 \\
3.84\end{array}$ & $\begin{array}{l}.032 \\
.16 \\
.11 \\
.081 \\
.20\end{array}$ & $\begin{array}{r}-.16 \\
-2.04 \\
-0.16 \\
-.74 \\
-1.31\end{array}$ & $\begin{array}{l}.051 \\
.24 \\
.13 \\
.13 \\
.028\end{array}$ & $\begin{array}{l}3.1 \\
8.5 \\
1.2 \\
5.7 \\
4.7\end{array}$ & $\begin{array}{l}<2 \\
<1 \\
30 \\
<1 \\
<1\end{array}$ \\
\hline
\end{tabular}

a Combined loss in weight of the anode and cathode. Area exposed, anode $=2.4$ in. ${ }^{2}\left(15.5 \mathrm{~cm}^{2}\right)$, cathode $^{2}=3.3 \mathrm{in} .{ }^{2}\left(21.3 \mathrm{~cm} .{ }^{2}\right)$

b Composition of steel, in percent: $0.23 \mathrm{C}, 0.58 \mathrm{Mn}, 0.008 \mathrm{P}, 0.025 \mathrm{~S}, 0.095 \mathrm{Si}, 0.077 \mathrm{Cu}$.

c Composition of cast iron in percent: $3.42 \mathrm{C}$ (total), 2.59 C'(free), 0.83 C (combined), 1.53 Si, 0.72 P, 0.68 Mn, $0.082 \mathrm{~S}, 0.05 \mathrm{As}$.

d $\sigma\left(w_{1}-w_{2}\right)=\sqrt{\left(\sigma_{w_{1}}\right)^{2}+\left(\sigma_{w_{2}}\right)^{2}} \quad$ (See text)

e $t=\frac{w_{1}-w_{2}}{\sigma\left(w_{1}-w_{2}\right)}$ (See text)

TABLE 3. Comparison of steel and cast iron after 12 years of field exposure

Loss in weight of field specimens

\begin{tabular}{|c|c|c|c|c|c|c|c|c|c|c|}
\hline \multirow{2}{*}{ Soil } & \multicolumn{3}{|c|}{ Steel } & \multicolumn{3}{|c|}{ Cast Iron } & \multirow{2}{*}{$\begin{array}{c}\text { Difference } \\
\text { between the } \\
\text { means, } X_{1}-X_{2}\end{array}$} & \multirow{2}{*}{$\begin{array}{l}\text { Standard error } \\
\text { of the differ- } \\
\text { ence, } \sigma_{X_{1}-X_{2}}\end{array}$} & \multirow{2}{*}{ Value of $t$} & \multirow{2}{*}{$\begin{array}{l}\text { Probability of } \\
\text { difference due } \\
\text { to chance }\end{array}$} \\
\hline & $\begin{array}{l}\text { Number of } \\
\text { specimens }\end{array}$ & $\begin{array}{c}\text { Mean } \\
X_{1}\end{array}$ & $\begin{array}{l}\text { Standard } \\
\text { error } \sigma_{X_{1}}\end{array}$ & $\begin{array}{l}\text { Number of } \\
\text { specimens }\end{array}$ & $\begin{array}{c}\text { Mean } \\
X_{2}\end{array}$ & $\begin{array}{l}\text { Standard } \\
\text { error } \sigma_{X_{2}}\end{array}$ & & & & \\
\hline $\begin{array}{l}4 \\
5 \\
8 \\
25 \\
26 \\
-\end{array}$ & $\begin{array}{l}6 \\
6 \\
6 \\
6 \\
6\end{array}$ & $\begin{array}{r}0 z / f t^{2} \\
6.6 \\
6.6 \\
7.5 \\
3.2 \\
3.6\end{array}$ & $\begin{array}{r}o z / f t^{2} \\
0.19 \\
.44 \\
.41 \\
.14 \\
.14\end{array}$ & $\begin{array}{l}4 \\
4 \\
4 \\
4 \\
4\end{array}$ & $\begin{array}{r}0 z / f t^{2} \\
15.1 \\
10.5 \\
21.2 \\
3.5 \\
4.1\end{array}$ & $\begin{array}{c}o z / f t^{2} \\
2.7 \\
3.3 \\
3.3 \\
.06 \\
.11\end{array}$ & $\begin{array}{r}0 z / f t^{2} \\
-8.5 \\
-3.9 \\
-13.7 \\
-.3 \\
-.5\end{array}$ & $\begin{array}{r}o z / \int t^{2} \\
2.7 \\
3.4 \\
3.4 \\
3.14 \\
.18\end{array}$ & $\begin{array}{l}3.1 \\
1.2 \\
4.0 \\
2.1 \\
2.8\end{array}$ & $\begin{array}{ll}\text { Percent } & <2 \\
& 28 \\
& <1 \\
5 & <2\end{array}$ \\
\hline $\begin{array}{l}32 \\
436 \mathrm{a} \\
62 \mathrm{a} \\
644^{\mathrm{a}}\end{array}$ & $\begin{array}{l}6 \\
6 \\
8 \\
8 \\
8\end{array}$ & $\begin{array}{r}3.7 \\
16.8 \\
30.5 \\
6.9 \\
50.9\end{array}$ & $\begin{array}{l}.25 \\
1.9 \\
2.3 \\
1.0 \\
9.0\end{array}$ & $\begin{array}{l}4 \\
4 \\
8 \\
8 \\
8\end{array}$ & $\begin{array}{r}4.8 \\
17.7 \\
40.5 \\
5.9 \\
58.0\end{array}$ & $\begin{array}{l}.59 \\
1.8 \\
6.8 \\
1.1 \\
5.8\end{array}$ & $\begin{array}{r}-1.1 \\
-.9 \\
-10.0 \\
+1.0 \\
-7.1\end{array}$ & $\begin{array}{r}.64 \\
2.6 \\
7.2 \\
1.5 \\
10.7\end{array}$ & $\begin{array}{r}1.7 \\
.3 \\
1.4 \\
.6 \\
.7\end{array}$ & $\begin{array}{l}14 \\
70 \\
18 \\
55 \\
50\end{array}$ \\
\hline
\end{tabular}

a Exposure 14 years.

using several soil samples collected at the test sites of the National Bureau of Standards and known to cover the range of corrosivity. The location of the test sites and some of the soil properties are given in table 1, along with other soils to be discussed later.

The results of the laboratory tests are given in table 2. In all of the soils, with the exception of soil 5, the steel electrodes were more resistant to corrosion than were the cast-iron electrodes. The significance of the difference indicated in the table is based on the standard $t$-test [8]. It will be noted that the better corrosion resistance exhibited by cast iron over steel in soil 5 may be attributed to chance.

\subsection{Comparison of Laboratory and Field Data}

A comparison of laboratory and field data pertaining to the corrosion of steel and cast iron is reasonable if the laboratory soil samples are representative of the soil in the trenches from which the field specimens were removed. The field data are shown in table 3. For all of the soils, except 56, 62 , and 64 , the data are based on weight losses reported by Logan [7] occurring on pipe specimens of Bessemer steel and on cast-iron pipe consisting of 2 de Lavaud specimens, 1 northern pit cast iron, and 1 southern pit cast-iron specimen. Data in table 3 pertaining to soils 56,62 , and 64 , were reported by Denison and Romanoff [6].

In all soils (table 3 ) except soil 62 , the steel specimens lost less weight than did the cast-iron specimens. The statistical significance of the difference in weight loss, as in the case of the laboratory comparison, is based on the $t$-test and, except in soils 62 , 43 , and 64 , shows substantially the same results. For soils 43 and 62 the laboratory and field comparisons of the corrosion of steel and cast iron are inconclusive; and in the case of soil 64 , the field data are so variable that any significant difference between the steel and cast iron is obscured. In soil 64 , the standard errors applying to the laboratory data (table 2) are relatively small. Therefore, the laboratory results in soil 64 are to be taken as being the more significant.

The preponderance of negative values in column 8 of table 3 is not to be considered as indicating the relative behavior of the materials in soils generally. 


\section{Measurement of Soil Corrosivity}

\subsection{Correlation Between Laboratory and Field Weight Losses}

In order to further evaluate the laboratory corrosion test as a measure of the relative corrosiveness of soils toward commonly used ferrous materials, the mean weight losses of steel electrodes after exposure for 6 months to the soils shown in table 1 were correlated with the average weight losses of other specimens exposed to the test sites for 10 years. The specimens at each test site totaled 8 in number and consisted of 2 of each of the following materials: Low-carbon steel, hand-puddled wrought iron, mechanically puddled wrought iron, and open-hearth iron.

In developing the laboratory test, the National Bureau of Standards was fortunate in having the cooperation of the Waterways Experiment Station, Corps of Engineers, U. S. Army. That laboratory followed the same procedure in measuring the corrosiveness of soils as described in section 2. The soil samples tested by the Waterways Experiment Station included 9 of the 10 soils studied by the National Bureau of Standards and in addition 5 soils removed from other National Bureau of Standards test sites. The 9 soils tested by both laboratories were not taken from the same samples but were removed from different parts of the trench at the 9 sites. Both laboratories used steel cell electrodes of the same chemical composition and dimensions. The composition and dimensions are given in table 2. The data obtained by both laboratories and the National Bureau of Standards field data are tabulated in table 4 . Correlation between the laboratory and field weight losses is based on the text of Croxton and Cowden [8]. The coefficient of correlation between the National Bureau of Standards laboratory and field data is 0.84 . The coefficient between the Waterways Experiment Station

TABLE 4. Correlation between combined laboratory and National Bureau of Standards field data

\begin{tabular}{|c|c|c|c|c|c|c|c|}
\hline \multirow{2}{*}{ Soil } & \multicolumn{3}{|c|}{$\begin{array}{l}\text { Weight loss of steel elec- } \\
\text { trodes after } 6 \text { months of } \\
\text { laboratory exposure }\end{array}$} & \multicolumn{2}{|c|}{$\begin{array}{l}\text { Weight loss of } \\
\text { wrought ferrous } \\
\text { specimens after } \\
10 \text { years of field } \\
\text { exposure }\end{array}$} & \multicolumn{2}{|c|}{$\begin{array}{l}\text { Maximum pit } \\
\text { depth on wrought } \\
\text { ferrous specimens } \\
\text { after } 10 \text { years of } \\
\text { field exposure }\end{array}$} \\
\hline & $\begin{array}{c}\text { National } \\
\text { Bureau } \\
\text { of Stand- } \\
\text { ards }\end{array}$ & $\begin{array}{l}\text { Water- } \\
\text { ways } \\
\text { Exp. } \\
\text { tion }\end{array}$ & $\begin{array}{c}\text { Average } \\
w\end{array}$ & Actual & $\begin{array}{c}\text { Calcu- } \\
\text { lated } \\
W_{10}\end{array}$ & Actual & $\begin{array}{c}\text { Calcu- } \\
\text { lated } \\
\mathrm{P}_{10}\end{array}$ \\
\hline $\begin{array}{l}4 \\
5 \\
8 \\
15 \\
25\end{array}$ & $\begin{array}{r}o z / f_{l}{ }^{2} \\
0.61 \\
1.97 \\
.89 \\
.20\end{array}$ & $\begin{array}{r}0 z / f t^{2} \\
0.91 \\
1.41 \\
1.27 \\
.86\end{array}$ & $\begin{array}{r}o z / f t t^{2} \\
0.76 \\
1.69 \\
.89 \\
1.27 \\
.53\end{array}$ & $\begin{array}{r}o z / f t t^{2} \\
6.4 \\
6.4 \\
5.5 \\
7.0 \\
2.6\end{array}$ & $\begin{array}{r}\text { oz/ft } 2 \\
5.3 \\
\text { a } 13.2 \\
6.4 \\
9.7 \\
3.4\end{array}$ & $\begin{array}{r}\text { Mils } \\
75 \\
50 \\
79 \\
63 \\
49\end{array}$ & $\begin{array}{r}\text { Mils } \\
63 \\
\text { a } 104 \\
69 \\
86 \\
53\end{array}$ \\
\hline $\begin{array}{l}26 \\
32 \\
41 \\
43\end{array}$ & $\begin{array}{c}.56 \\
.37 \\
1.36\end{array}$ & $\begin{array}{r}.48 \\
.56 \\
.32 \\
2.18 \\
.43\end{array}$ & $\begin{array}{r}.52 \\
.46 \\
.32 \\
1.77 \\
.43\end{array}$ & $\begin{array}{r}2.5 \\
3.1 \\
6.1 \\
12.6 \\
3.2\end{array}$ & $\begin{array}{r}3.3 \\
2.8 \\
1.6 \\
13.9 \\
2.5\end{array}$ & $\begin{array}{r}59 \\
55 \\
64 \\
112 \\
75\end{array}$ & $\begin{array}{r}53 \\
50 \\
44 \\
108 \\
49\end{array}$ \\
\hline $\begin{array}{l}56 \ldots \ldots \ldots \\
61 \ldots \ldots \\
64 \ldots \ldots \\
65 \ldots \ldots \ldots\end{array}$ & $\begin{array}{l}1.05 \\
2.53\end{array}$ & $\begin{array}{r}3.23 \\
1.69 \\
.91 \\
1.49 \\
1.03\end{array}$ & $\begin{array}{r}2.70 \\
1.69 \\
.98 \\
2.53 \\
1.03\end{array}$ & $\begin{array}{r}21.2 \\
7.1 \\
6.2 \\
30.0 \\
11.9\end{array}$ & $\begin{array}{r}21.7 \\
13.2 \\
7.2 \\
20.3 \\
7.6\end{array}$ & $\begin{array}{r}132 \\
72 \\
78 \\
145 \\
100\end{array}$ & $\begin{array}{r}148 \\
104 \\
73 \\
141 \\
75\end{array}$ \\
\hline
\end{tabular}

a See text, section 4 . data and the National Bureau of Standards field data is 0.6 , but by eliminating soil 64 the coefficient becomes 0.87 .

Because the soils listed in table 4 cover the range of corrosivity of soils peculiar to the United States, the data of both laboratories are used to set up the equation of best fit [9], presumably a linear relationship, between the laboratory and field weight losses, which it is again presumed will be applicable to any soil, whatever its degree of corrosivity. The standard errors associated with the weight losses were about the same for both laboratories except for the Waterways Experiment Station data pertaining to soil 64, in which the standard error was considerably larger than for all other data. As the inclusion of soil 64 adversely affected the correlation between the Waterways Experiment Station data and the field data, the Waterways Experiment Station data pertaining to this soil are omitted. Thus, by averaging the weight losses in each of 8 soils $(4,5,25,26,32,43$, 56,62 , table 4 ) tested by the two laboratories and using the individual laboratory weight losses in the 7 other soils $(8,15,41,55,61,64,65$, table 4$)$, the correlation between the combined laboratory weight losses and the National Bureau of Standards weight losses in the field results in a correlation coefficient of 0.83. All correlation coefficients were corrected for size of sample. Based on the correlation coefficient of 0.83 , the equation relating the laboratory and field data is

$$
W_{10}=8.45 w-1.1 \text {, }
$$

where $W_{10}$ is the anticipated weight loss on the commonly used ferrous specimens after 10 years of field exposure, expressed in ounces per square foot. $w$ is the mean combined weight loss in 6 months of the anode and cathode of corrosion cells, expressed in ounces per square foot. The standard error of estimate associated with this relationship is $\pm 4.1 \mathrm{oz} / \mathrm{ft}^{2}$.

The calculated weight losses on the National Bureau of Standards specimens based on eq (1) are tabulated in table 4, along with the actual weight losses. Relatively large discrepancies appear between the actual and calculated values in soils 5, 41, and 61. In the case of soils 41 and 61, the discrepancies might be attributed to the laboratory test. Soil 5, however, is fine in texture, very dense, and poorly aerated, and also possesses other characteristics which Denison and Ewing [10] associated with very corrosive soils. Also, a reference to some early information published by Logan, Ewing, and Yeomans [11] revealed that iron pipe removed from soil 5 was severely corroded. Probably the conditions within the trench from which the field specimens were removed were not typical of the general soil structure. Therefore, for soil 5 at least, the laboratory data are considered a better index of the potential soil corrosivity than are the field data.

\subsection{Correlation Between Weight Loss and Maximum Penetration}

The value of a laboratory corrosion test would be immeasurably increased if it could be used to predict the maximum depth of pitting under normal 
field exposure. Laboratory weight losses might be interpreted in terms of pit depths if it could be shown that a correlation existed between weight loss and maximum penetration on ferrous specimens after field exposure. To test this possibility, 2 specimens of each of 4 commonly used wrought ferrous materials, previously described, exposed for 10 years at 58 National Bureau of Standards test sites were chosen. Following the statistical procedure already referred to, the average depths ${ }^{2}$ of the deepest pits on these specimens were correlated with the average weight losses. The coefficient of correlation was calculated to be 0.79 . The equation, based on this correlation, relating weight losses and pit depths for the 58 soils after 10 years of exposure is

$$
P_{10}=5.2 W_{10}+36
$$

where $P_{10}$ is the maximum pit depth in mils on an area of $0.4 \mathrm{ft},{ }^{2}$ and $W_{10}$ is the weight loss expressed in ounces per square foot. The standard error of estimate pertaining to $P_{10}$ in this equation is \pm 18 mils. Because of the number and variety of soils included in the derivation of eq (2), the relationship might be considered as being generally applicable to wrought ferrous materials exposed to any soil. Additional evidence of some correlation between weight loss and pitting on wrought and also cast ferrous specimens is indicated by the studies of Denison and Romanoff [6].

By combining eq (1) and (2), the maximum anticipated pit depth at 10 years is related to the laboratory weight loss for 6 months by the relation

$$
P_{10}=43.9 w+30 \text {, }
$$

where $P_{10}$ is expressed in mils at 10 years on an exposed area of $0.4 \mathrm{ft}^{2}$ and $w$ is as expressed for eq (1). Included in table 4 are the actual maximum pitdepths measured on the field specimens and also the calculated values based on eq (3). The lack of reasonably good agreement in soil 5 is to be expected because of the facts previously pointed out concerning this soil.

\section{Adjustment for Time and Exposed Ārea}

It has been shown that by means of the laboratory corrosion test a resonable estimate can be made of the weight loss and the average depth of the deepest pit that will occur on iron and steel specimens exposed in the field for 10 years. Obviously, the practical value of the test would be enhanced if it were possible to predict similar information as applied to larger exposed areas and periods of exposure other than 10 years.

Martin [12] has shown that the relation between the weight loss of iron and steel in soils and the duration of exposure may be expressed by the empirical equation

$$
W=k^{\prime} T^{u}
$$

2 The average of the deepest pits on 8 specimens is also referred to as the maximum pit depth. where $W$ is the weight loss at any time $T, k^{\prime}$ is the weight loss on a unit area for a unit time, and $u$ is a constant peculiar to the soil.

Similarly, Logan, Ewing, and Denison [4] have shown that the average depth of the deepest pits on iron and steel may be expressed by the empirical equation

$$
P=k T^{n} A^{a},
$$

where $P$ is the average depth of the deepest pits at any time $T$ on the exposed area $A$, and $k$ is the average value of the depth of the deepest pits on specimens of unit area for a unit time. The exponents $n$ and $a$ are constants, $n$ depending on the aeration and drainage of the soil, and $a$ being relatively fixed in all soils.

For a practical application of these equations to any soil, appropriate values must be selected for the exponents. Logan, Ewing, and Denison tabulated values for exponent $a$ based on exposure tests of wrought ferrous specimens in 47 soils. They concluded that the value of $a$ could not be characterized by any particular soil property. As the values reported did not vary over too wide a range, the writer believes that some average value would be appropriate for all soils. By eliminating all soils in which the associated standard errors tabulated for $a$ exceeded 20 percent, the values of $a$ for the remaining 31 soils ranged between 0.082 and 0.241 , averaging 0.15 , with a standard error of 0.019 .

Logan, Ewing, and Dension divided the 47 soils into 4 groups based on aeration and drainage and calculated the average value of the exponent $n$ for each group. These values of $n$ and the associated standard errors are shown in table 5. Average values for $u$ and standard errors based on 14-year exposure tests of wrought ferrous materials by Denison and Romanoff [6] are included in the same table. It will be observed that the values of both $n$ and $u$ bear an inverse relation to the degree of soil aeration.

TABLE 5. Average values of the time exponents $n$ and $u$ for soil groups differing in aeration

\begin{tabular}{|c|c|c|c|}
\hline \multicolumn{3}{|c|}{ Group I, Good aeration } \\
\hline$n$ s & $\sigma_{n}$ & $u$ s & $\sigma_{u}$ \\
\hline 0.19 & 0.03 & 0.23 & 0.10 \\
\hline \multicolumn{2}{|c|}{ Group II, Fair aeration } \\
\hline 0.35 & 0.03 & 0.42 & 0.12 \\
\hline Group III, Poor aeration \\
\hline 0.47 & 0.04 & 0.74 & 0.14 \\
\hline Group IV, Very poor aeration & IV \\
\hline 0.68 & 0.10 & 0.77 & 0.09 \\
\hline
\end{tabular}

a Values for $n$ and the associated standard errors $\sigma_{n}$ are the mean values reported by K. H. Logan, S. P. Ewing, and I. A. Denison, Symposium on corrosion ported by K. H. Logan, S. P. Ewing, and I. A. Denison, Symposium on corrosion
testing procedures, ASTM (Phila. Pa, 1937). Values for $u$ and the associated standard errors $\sigma_{u}$ are average values taken from I. A. Denison and Melvin standard errors $\sigma_{u}$ are average values taken from
Romanoff, J. Research NBS 44, 47 (1950) RP2057. 
TABLE 6. Time exponents $n$ and $u$ associated with soils of different properties

\begin{tabular}{|c|c|c|c|c|}
\hline Soil group... & $\mathrm{I}$ & II & III & IV \\
\hline Values, $n$ or $u$ & $0.19 \ldots$ & $0.35_{-}$ & 0.47 & 0.68 \\
\hline Aeration and drainage & Good & Fair & Poor & Very poor. \\
\hline Soil texture ................... & $\begin{array}{l}\text { Sands and sandy loams, light- } \\
\text { textured silt loams, porous } \\
\text { loans, clay loams. }\end{array}$ & $\begin{array}{l}\text { Sandy loams, silt loams, clay } \\
\text { loams. }\end{array}$ & Clay loams, clay & $\begin{array}{l}\text { Clays and organic soils, in- } \\
\text { cluding tidal marshes. }\end{array}$ \\
\hline Depth of mottling in inches_. & None & 18 to 24 & 6 to 8 & 6 to 8. \\
\hline Color of subsoil & Uniform & Slightly mottled-yellowish & Moderately mottled-gray & Mottled-bluish gray. \\
\hline Height of water table.. & Very low ... & Low & 2 to $3 \mathrm{ft}$ below the surface & At the surface. \\
\hline
\end{tabular}

Also, if the values for $n$ and $u$ are compared, giving consideration to the standard errors, the mean values for $n$ and $u$ overlap, except for group III. Because the values for $u$ are based on relatively few soils as compared with the values shown for $n$, the later are taken to be the more significant. For this reason, because of what has already been shown concerning the correlation between weight loss and maximum penetration, the writer believes that the values for $n$ shown in table 5 can be applied to $T$ in both the weight loss and pit-depth equations. Accordingly, this is proposed in table 6 , together with the distingushing soil properties pertaining to the four groups.

Having obtained from the laboratory test a value for the average depth of the deepest pit at 10 years, $P_{10}$ on $0.4 \mathrm{ft}^{2}$ (eq 3 ), the value of pitting for a time $(T)$ other than 10 years and for an area $(A)$ greater than $0.4 \mathrm{ft}^{2}$ is calculated from the equation

$$
P=P_{10}\left(\frac{T}{10}\right)^{n}\left(\frac{A}{0.4}\right)^{0.15}
$$

It has been pointed out by Logan, Ewing, and Denison that the values substituted for $T$ and $A$ cannot be chosen indiscriminately. This is particularly true when substituting for $A$, because $P_{10}$ applies to $0.4 \mathrm{ft}^{2}$. A reasonable extrapolation based on soils 55 and 56 (table 4) might be considered. Assuming an area $(A)$ of $20 \mathrm{ft}^{2}$ (approx. $20 \mathrm{ft}$ of $3 \frac{1}{2}$-in. steel pipe) and an underground-exposure period $(T)$ of 40 years, the maximum predicted pit depths calculated from eq (4) would be 112 mils, and 660 mils for soils 55 and 56 , respectively. In these calculations, values of $n=0.19$ and $n=0.68$ were chosen for soils 55 and 56 , respectively, the values being selected from table 6 on the basis of the soil properties found in table 1 . Thus, in the case of soil 55 the increase in pit depth after 10 years is due chiefly to the increased area, whereas the deeper pits resulting from soil 56 are attributable mainly to the effect of time.

Weight losses at 10 years, based on the laboratory test (eq 1), can be similarly adjusted and values of weight loss $(W)$ predicted for periods $(T)$ other than 10 years. The weight loss becomes

$$
W=W_{10}\left(\frac{T}{10}\right)^{u},
$$

where $u$ is selected from table 6 , based on the soil properties. The effect of area on weight loss is assumed to be linear. This equation is particularly useful in calculating the average penetration by conversion. Thus the average penetration in mils becomes

$$
\bar{P}=1.53 W,
$$

where $W$ is the weight loss in ounces per square foot $(\mathrm{eq}(5))$. The predicted average penetration on a steel surface exposed to soils 55 and 56 (table 4) for 40 years would be 5 mils and 81 mils, respectively. Such information is useful where loss of strength is the primary consideration.

\section{Summary}

A modification of the Denison soil-corrosion cell is described. The cells were assembled in quadruplet with both steel and cast-iron electrodes exposed to 10 soils of varying degrees of corrosivity. Because the corrosion rate of ferrous metals in soils is a function of time all measurements are based on the weight loss of the electrodes after 6 months of exposure.

In 9 of the soils, the steel electrodes lost less weight than the cast-iron electrodes. Statistically expressed, the difference in weight loss in 5 of these soils being due to chance was less than 1 percent and in 2 other soils less than 4 percent. The laboratory results compare favorably with 12 -year field exposure tests.

Good correlation was also obtained between the weight losses of the corrosion cells and the weight losses occurring in the field on other wrought ferrous specimens exposed for 10 years to the same soils. Based on 10-year field exposure of wrought materials at 58 test sites throughout the United States, a fair correlation was found to exist between weight loss and maximum penetration. By making use of the latter correlation, it is shown how laboratory weight losses can be used to predict probable maximum pit depths on ferrous materials upon field exposure after 10 years.

By utilizing equations relating weight loss of ferrous field specimens to time of exposure, and the average depth of the maximum pits on the specimens to time and to exposed area, values of weight loss and pitting at the end of 10 years predicted by the laboratory test may be extrapolated to any desired area and period of exposure within reasonable limits. Suggested values of the exponents required for adjustment of the data are given. 
The author gratefully acknowledges the contribution of the Waterways Experiment Station, Vicksburg, Miss., Corps of Engineers, U. S. Army. Thanks are due O. B. Ellis, Armeo Steel Corp., and James T. MacKenzie, American Cast Iron Pipe Co., for furnishing the materials for the cell electrodes. The writer acknowledges the suggestions and assistance of O. N. McDorman of the National Bureau of Standards relative to the preparation of the cell and the assistance in statistical calculations by Andrew J. Griest, Jr., formerly with the National Bureau of Standards.

\section{References}

[1] Scott Ewing, Soil corrosion and pipe line protection, p. 78 (American Gas Assn., 420 Lexington Ave., New York, N. Y.).

[2] I. A. Denison, Electrolytic measurement of the corrosiveness of soils, J. Research NBS 17, 363 (1936) RP918.

[3] I. A. Denison and R. B. Darnielle, Observation on the behavior of steel corroding under cathodic control in soils, Trans. Electrochem. Soc. 76, 199 (1939).

[4] K. H. Logan, S. P. Ewing, and I. A. Denison, Soil corrosion testing, Symposium on corrosion testing procedures, ASTM (1937)

[5] W. J. Schwerdtfeger and O. N. MeDorman, Measurement of the corrosion rate of a metal from its polarizing characteristics, J. Electrochem. Soc. 99, 407 (1952).

[6] I. A. Denison and Melvin Romanoff, Soil-corrosion studies, 1946: Ferrous metals and alloys, J. Research NBS 44, 47 (1950) RP2057.

[7] Kirk H. Logan, Underground corrosion, NBS Circular C450 (1945).

[8] Croxton and Cowden, Applied general statistics (Prentice-Hall, Inc., New York, N. Y., 1940).

[9] Ezekiel, Methods of correlation analysis (John Wiley \& Sons, Inc., New York, N. Y., 1930; Chapman \& Hall, Ltd., London, 1930).

[10] I. A. Denison and S. P. Ewing, Corrosiveness of certain Ohio soils, Soil Science 40, 287 (1935).

[11] K. H. Logan, S. P. Ewing, and C. D. Yeomans, Soilcorrosion studies. 1. Soils, materials, and results of early observations, Tech. Pap. BS No. 368 (April 28, 1928).

[12] L. M. Martin, A preliminary study of the logarithmic relation between corrosion and time, NBS Soil Corrosion Conference 1937, unpublished.

\section{Appendix}

\subsection{Preparation of the Corrosion Cell}

The apparatus for moistening and adjusting the water content of the soil samples is shown diagramatically in figure 3 . Because 4 cells are desirable for testing a soil, the apparatus provides for simultaneously moistening the soil contained in 8 Lucite cylinders. Distilled water absorbed from the water dispenser, 12, resting on the upper surface of the soil, 9, is distributed uniformly throughout the soil by a pressure difference of $30 \mathrm{~cm}$ of $\mathrm{Hg}$. Suction is applied to $500-\mathrm{ml}$ suction flasks, 3, through fritted-disk Buechner funnels, 1, (150 ml, fine) to the soil contained in the Lucite cylinders, 7 . Paraffin, 8, serves to confine the suction to the soil. The battery of eight suction flasks are connected to the suction apparatus with rubber tubing and glass fittings. The vacuum in the line is controlled by valve, 5, and to each flask by valve, 4 .

Details of a water dispenser, 12 , are shown under detail C, figure 3. The reservoir, $\mathrm{A}$, is cut from Lucite tubing of 1.75 -in. OD and 0.125 -in. wall thickness. The bottom edge, $B$, is tapered or rounded so that it will fit readily into the cylinder containing the soil. The dispenser is assembled as follows: With the reservoir placed on a flat surface in the

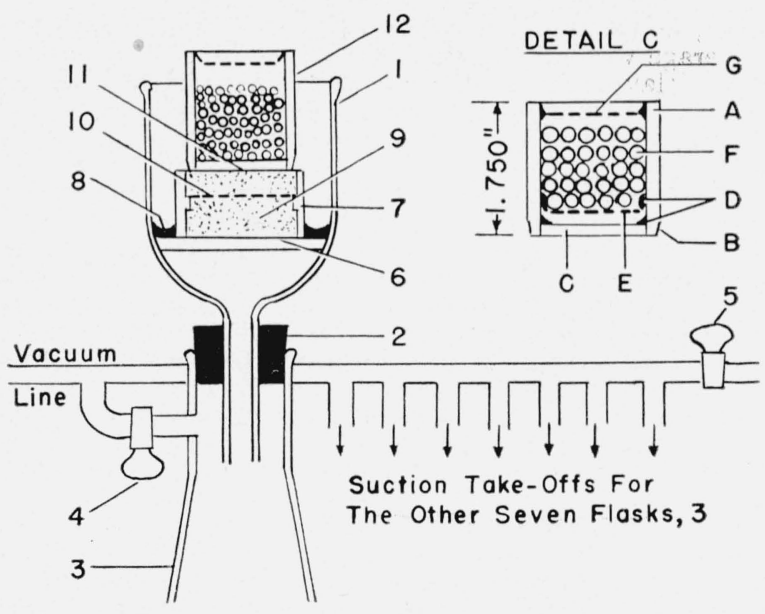

Figure 3. Cross-sectional view of the soil-moistening apparatus.

position shown, asbestos paper, C, 0.125 in. thick cut into the form of a disk slightly larger than the inside diameter of the tubing, is pressed from the top to the bottom and sealed with molten beeswax, D. A saucer shaped stainless steel screen (16 mesh), E, held in place by friction and beeswax, serves to keep the weight of the glass beads, F, off of the asbestos. The beads (6-mm solid glass) added to within $1 / 2$ in. from the top of the dispenser furnish weight to insure good contact for absorption of water by the soil. A second screen, $G$, identical with screen, $\mathrm{E}$, is pressed over the glass beads to prevent their loss.

The cell electrodes (fig. 1) are prepared for the corrosion tests in the following manner: The electrodes are degreased and all burrs removed with $1 \mathrm{G}$ French emery cloth. After being weighed, the electrodes are fitted with 0.5 in. $\times 2-56$ steel fillister head machine screws and stranded copper wire (RC No. 18) leads, approximately 8 in. long, are soldered under the heads. The edges and unfinished surfaces of the anodes are given a heavy coat of bituminous paint. The edges and unfinished sides of the cathodes, excluding the cylindrical surface of the holes, are similarly treated. The machine screws and soldered connections are also coated to prevent corrosion and to facilitate removal of the screws at the conclusion of the test.

In setting up the corrosion cells eight Buechner funnels, 1, are fitted with rubber stoppers, 2 , and positioned as shown in figure 3. Two sheets of filter paper (No. $42-5.5-\mathrm{cm}$ diam), 6 , are placed in each funnel to prevent direct contact between the soil and the fritted glass. The screw holes in the Lucite cylinders, 7, are filled with saturated soil and a cylinder is centered in each funnel. Paraffin is heated just to the melting point and a sufficient amount applied with a dropper to the space around each of the cylinders to adhere to both the funnel and the cylinder. Dry soil previously passed through a No. 20 standard sieve is poured into each cylinder approximately to the upper edge of the ridge and compacted by placing a cylindrically shaped brass weight 1.75 in. in diameter and $2.25 \mathrm{in}$. long on the surface of the soil. Disks of stainlesssteel wire mesh, 10 , are then placed on the ridges of 4 of the 8 cylinders, and the process of filling the cylinders and compacting the soil is resumed until all of the cylinders are filled. As excessive swelling usually accompanies the moistening of heavy clay soils, allowance for this may be made by filling the cylinders just short of capacity.

After the asbestos of the water dispensers is saturated with distilled water, $15 \mathrm{ml}$ of water are poured into each of the reservoirs and the dispensers then positioned on the surfaces of the soil samples but separated therefrom by a sheet of filter paper, 11, cut to conform to the inside diameter of the cylinder. Vacuum equivalent to $30 \mathrm{~cm}$ of $\mathrm{Hg}$ is then applied for periods ranging from 1 to $8 \mathrm{hr}$, depending on the soil texture. Sufficient moistening of the soil is indicated by water dripping from the funnels, sweating underneath the fritted glass, or by the appearance of the soil. The valve, 4 , to the particular cell is then closed and the water dispensers removed. 
Usually, all sections are sufficiently wet within 20 percent of the average wetting time peculiar to the soil. If it is necessary to delay assembly of the cell, evaporation of water can be prevented by covering the soil with a pad of cheesecloth saturated with water and the funnel with an inverted crystallizing dish.

The cell components are assembled in the following manner: The adhesion between the paraffin around the Lucite cylinders and the funnels is broken with a spatula, and the four funnels containing the cylinders fitted with the screen disks $\mathrm{D}$, are removed. The four funnels are inverted, and the cell sections are dropped into the palm of the hand. The four cylinders, paper-capped ends down, are placed on a flat surface, and the soil on the upper surface of the cylinders is slicked over with a spatula occasionally dipped into distilled water until all evidence of porosity has disappeared. The unpainted surfaces of four anodes (A, fig. 1) are lightly scratched with $1 \mathrm{G}$ French emery cloth and cleaned with distilled water. The anode is again moistened with distilled water, the screw alined with the notch in the Lucite cylinder, and with an oscillatory motion combined with some pressure, the anode is placed in good contact with the soil. Excess soil is then removed, the components wiped dry, and the junction of the anode and the cylinder sealed with molten asphalt. The paraffin seal around the Lucite is loosened with a spat- ula, and the cylinders are turned over so as to rest on the anodes, after which the filter paper and adhering paraffin are lifted off in preparation for the positioning of the cathodes.

The cathodes (B, fig. 1) are prepared in the manner described for the anodes and positıoned over the soil in the ends of these four inverted cylinders, previously described, with the uncoated surfaces facing the anodes. The cathode perforations are then filled with dry soil. The four remaining soil cylinders are removed from the funnels and positioned over the cathodes so that the edges from which the paraffin was removed are adjacent to the cathodes. The screen disk, $\mathrm{E}$, is positioned, and the components are joined with molten asphalt, as shown in figure 1 . The rubber stopper, $\mathrm{H}$, is then placed in position and held firmly against the anode by a No. 32 rubber band, $\mathrm{G}$, wrapped once around the stopper and the cell. Each cell is placed on nonconducting supports in a 1quart friction-top can containing about $25 \mathrm{ml}$ of water to maintain a saturated atmosphere. The water level is maintained throughout the period of the test. Leads from the cell are passed through holes in the side of the can and the electrodes short-circuited by a Fahnestock clip soldered to one of the wires.

Washington, March 6, 1953. 